TP Periodica Polytechnica

58(2), pp. 149-156, 2014

DOI: $10.3311 /$ PPch.7204

Creative Commons Attribution (1)

RESEARCH ARTICLE

\section{Application Possibilities of Zeolite Catalysts in Oligomerization of Light Olefins}

\author{
Eszter Kriván ${ }^{1 *} /$ Szabina Tomasek $^{1}$ / Jenö Hancsók ${ }^{1}$ \\ RECEIVED 5 DeCEMBer 2013; ACCEPTED AfTER REVISION 31 JanUary 2014
}

\begin{abstract}
In recent decades, the application of more zeolite-type catalysts has been studied in oligomerization reaction. In the oligomerization process various boiling-range isoolefins can be produced which can be hydrogenated to isoparaffins. The oligomerization of olefins in the light FCC gasoline-matrix in the presence of zeolites has not yet been reported. Therefore, our objective was to select a catalytic system that is suitable for producing isoolefin mixtures from the referred feedstock. The activity of the studied catalytic systems was similar, but with the use of the two layered bed the share of oligomers in middle distillate boiling point range was doubled. In the favourable reaction conditions (two layered bed, T: $270^{\circ} \mathrm{C}, \mathrm{P}: 40 \mathrm{bar}, \mathrm{LHSV}: 1.0 \mathrm{~h}^{-1}$ ) such isoolefin mixtures can be produced from which after hydrogenation excellent, environmentally friendly gasoline, JET, and diesel fuel blending components can be obtained.
\end{abstract}

\section{Keywords}

oligomerization $\cdot$ light olefins $\cdot$ FCC naphtha $\cdot$ motor fuel

\section{Introduction}

The motor fuel demand of the world, especially for middle distillates, continues to grow in the European Union. To meet the current stringent quality requirements, such gasoline and diesel gas oil blending components are necessary which contain only a reduced amount of aromatic compound and are practically heteroatom-free, their octane or cetane number is high, and they also consist of easy and clean burning compounds. The isoparaffins are excellent blending components because their excellent physical-chemical and performance properties, and their blending into the motor fuels is not limited by standards [1]. Directives issued by the European Standardisation Committee (CEN) in 2010 suggest the production of high paraffin containing motor fuel blending components, which can be used mainly as diesel fuel blending components [2].

One method of production of isoparaffins is the hydrogenation of isoolefin mixture formed in oligomerization of light olefins (3-6 carbon atoms) (Figure 1). One of the great advantages of the technology is that it can produce more valuable products from less valuable hydrocarbon industrial by-products, which can be formed in different technologies (fluid catalytic cracking of distillates, steam cracking, cracking of waste plastics and other thermal technologies, Fischer-Tropsch synthesis). Another advantage is that the oligomerization is flexible in terms of the average molecular weight of the hydrocarbon product and thus in terms of the composition (gasoline, JET, and gas oil fractions). The oligomerization has already been studied by using a variety of catalysts [3], such as solid phosphoric acid [4-6], zeolites [7-15], acidic ion exchange resins [14-20], metal oxide catalysts [21-22] and ionic liquids [23-26].

Over the past decades the application of many types of zeolite catalysts were studied in oligomerization reactions. As a feedstock model compounds were mainly used. At the end of the 1990's Nkosi et al $[7,8]$ studied the modification of the Y-zeolites to use in the oligomerization of butenes. It was found that the lower acidity favours the production of dimers. When the catalyst activity increased, the deactivation rate increased, too. With increasing the size of the modifying cations the dimer selectivity increased. Yoon et al recently studied the oligomerizing activity 


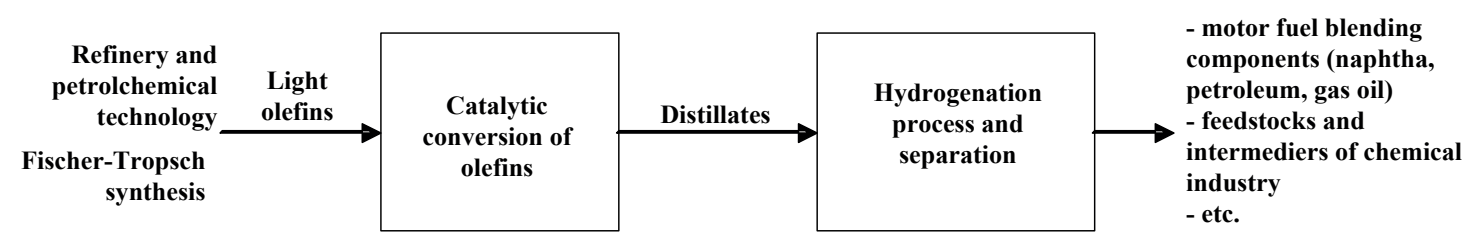

Fig. 1. Conversion of light olefins to motor fuels

of many solid acid catalysts [9-14], primarily isobutene trimerization on different zeolite catalysts (e.g. beta zeolite, USY zeolite, mordenite, ferrierite). Based on the results they found that from the tested catalysts beta zeolites are suitable for oligomerization. During their investigations it was concluded that a higher share of oligomeric product with a higher degree can be achieved in case of higher Lewis/Brønsted acid ratio.

Several groups have also dealt with using ZSM type catalysts (especially ZSM -5) for the oligomerization reactions in the past 10 years [3,12-13,27-29]. Arno de Klerk compared the activity of several catalysts (H-MCM-41, amorphous $\mathrm{SiO}_{2}-$ $\mathrm{Al}_{2} \mathrm{O}_{3}$, UOP SPA, MOGD-1, MOGD-2) to oligomerize 1-hexene and 1 -octene $[3,12-13]$. It noted that above $200^{\circ} \mathrm{C}$ a cracking side reaction occurred in the case of the tested catalysts, too. The resulting products were primarily middle distillates. Hauge et al [27] studied the dimerization of isobutene on various zeolite type catalysts (HZSM-5, H-mordenite, $\beta$-zeolite, Y-zeolite) as well. It was found that after the initial high conversion they deactivated quickly. This is because of the pore clogging effect of higher oligomeric hydrocarbons formed in the pores. Kresnawahjuesa et al [28] applied H-ZSM-5 catalyst in propylene and 1-butene oligomerization. Primarily they studied the adsorption properties of the various hydrocarbons. It was found that the activity of the tested $\mathrm{H}-[\mathrm{Fe}]-\mathrm{ZSM}-5$ was less than that of H-[Al]-ZSM-5 catalysts. Schmidt et al [29] studied the oligomerization of the olefin content of a mixture modelling an refinery $\mathrm{C}_{5}$ fraction with mordenite and ZSM-5 catalysts. Based on the results it was found that the higher $\mathrm{Si} /$ $\mathrm{Al}$ ratio effected higher conversion of the alkenes (mordenite, isopentane conversion: 95\%, linear pentene conversion: $25-45 \%$, dimer selectivity: $92-95 \%$ ). The catalyst worked steadily at a constant temperature during the 600 hours long term experiment.

Three patented technologies are based on this type of catalyst: the MOGD (Mobil Olefins to Gasoline and Distillate), COD (Catalytic Conversion of Olefins to Distillates) and EMOGAS (Exxon Mobil Olefins to GASoline) [3,30]. The MOGD process was developed in the 1980's applying H-ZSM-5 catalyst especially for the purpose of oligomerization of olefins obtained on methanol basis. The COD technology [3] used H-ZSM-5 catalyst for the conversion of Fischer-Tropsch olefins to diesel gas oil. In the 2000's EMOGAS technology was developed which was suitable for the production of mainly gasoline and JET fractions on H-ZSM-22 or -57 zeolite [3].
The previous publications mainly reported on laboratory scale experiments carried out with model compounds, mostly in relation to the production of dimers. Technologies patented on zeolite catalysts are related to feedstocks with specific compositions and characterized by a given technology. No publications were written about the conversion of the olefins in light FCC gasoline in the presence of zeolites. Therefore, our research was to select a catalytic system which is suitable for producing much more valuable intermediates (isoolefin mixtures) from the referred feedstock, namely a less valuable byproduct, from which motor fuel blending components can be prepared after hydrogenation.

\section{Experimental}

In our experimental work - based on the previous reasons we examined the oligomerization of the olefin content of light FCC gasoline on different zeolite catalysts. We studied in detail the effect of the process parameters (temperature, pressure, LHSV: liquid hour space velocity) on the yield and selectivity of the target products.

\subsection{Apparatus}

The experiments were carried out in a high pressure laboratory scale reactor system (Figure 2). The reactor length is 480 $\mathrm{mm}$, the internal diameter is $25 \mathrm{~mm}$ (in the middle of the reactor there is a thermometer to measure the temperature of the catalyst bed). The volume of the loaded catalyst is approx. 100 $\mathrm{cm}^{3}$, inert loading was preferably placed in the lower and upper section of the reactor. The loaded catalyst bed is around $22 \mathrm{~cm}$ high. To control the temperature of the middle of the bed we used heating elements situated in the reactor shell. The heater is divided into two separate parts, temperature is measured in two places, and with these the desired temperature of the catalyst bed can be set with $\pm 1{ }^{\circ} \mathrm{C}$ accuracy. The reactor system contained all the equipment, apparatus and machines which can be found in an industrial plant, too.

\subsection{Process parameters}

The process parameters were chosen based on the results of our earlier experiments. The investigated temperature range was $80-260^{\circ} \mathrm{C}$ and $180-300^{\circ} \mathrm{C}$, pressure range was $30-60$ bar, liquid hourly space velocity range was 1.0 and $2.0 \mathrm{~h}^{-1}$.

During the experiment the feedstock was thermostated at nearly $0-5^{\circ} \mathrm{C}$ in the storage and feeding burettes. The measurements 


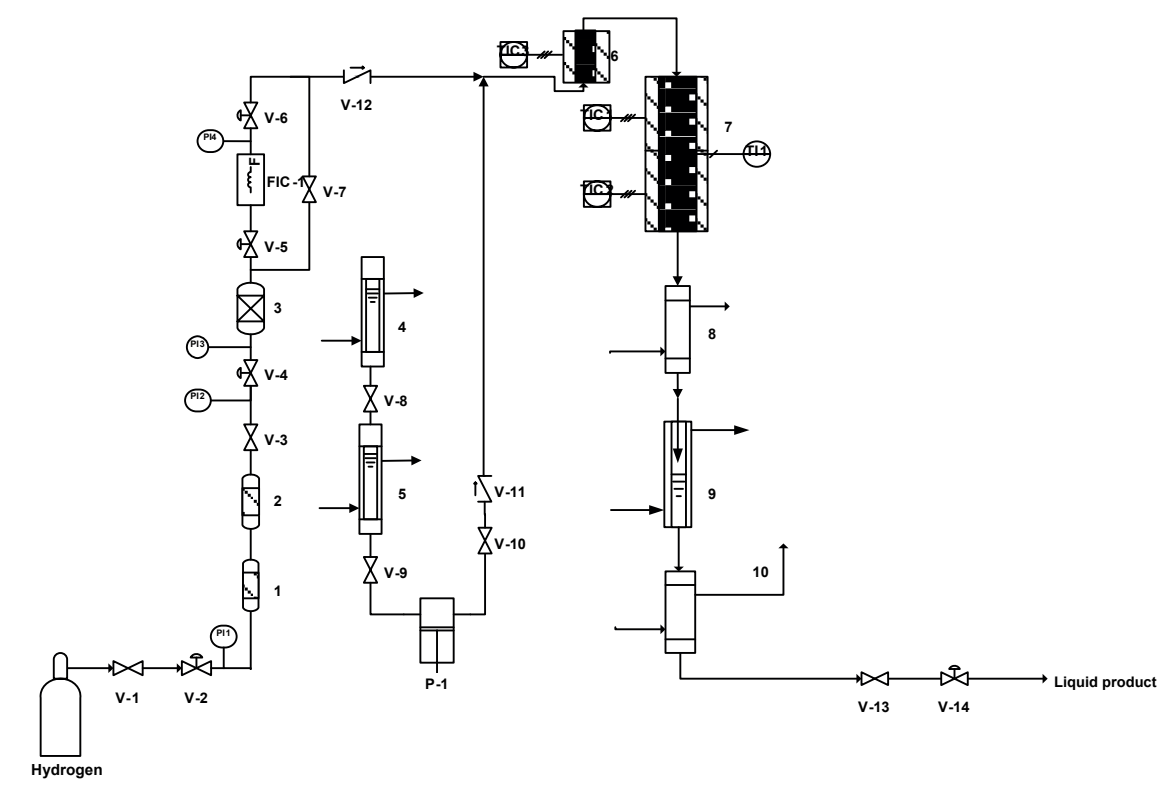

Fig. 2. Simplified scheme of the test apparatus

(1 oxygen converter; 2 gas dryer; 3 gas filter; 4, 5 burettes for liquid feed; 6 pre-heater; 7 reactor; 8, 10 cooler; 9 separator; V-1, V-3, V-7, V-8,V-9, V-10, V-13 closing valves; V-2, V-4, V-5, V-6, V-14 control valve; V-11, V-12 back valve; PI1, PI2, PI3, PI4 manometers; P-1 pump; FIC-1 gas flow meter/controller)

were carried out in nitrogen atmosphere. We started the main periods of each measurement point only after the system was in a steady state regarding both the process parameters and the composition of the product. The state of the laboratory experimental apparatus was considered stabilized if the individual process parameters changed only between the allowed limits $\left( \pm 1^{\circ} \mathrm{C}\right.$, \pm 0.2 bar, $\pm 1 \mathrm{~cm}^{3} /$ hour) for $3-5$ hours, and the composition of the resulting product mixture varied between the combined error limits of the technological measurement and the analytical test.

\subsection{Analytical methods}

The yield of liquid products was determined with mass measurement and the yield of gas product with gas flow meter and was verified from the mass balance. The composition of gas products was determined with online gas chromatography (Thermo-Finnigan Trace 2000 GC; Varian column: 50 m x 0.2 $\mathrm{mm} \times 0.5 \mu \mathrm{m}$; TCD detector).

The boiling point range of the products and the characteristic of the boiling point curve were characterized by Engler distillation (EN ISO 3405:2000). We examined the composition of the liquid hydrocarbon products with gas chromatography method. The $0.1 \mu$ fluid sample was injected through PTV (Programmed Temperature Valve) injector $\left(5 \mathrm{~min}\right.$ at $30^{\circ} \mathrm{C}$, to $350^{\circ} \mathrm{C}$ at $20^{\circ} \mathrm{C} / \mathrm{min}$ ramp rate, and holding time $5 \mathrm{~min}$ ). The Shimadzu GC-2010 gas chromatograph is equipped with a ZB-1 column $(100 \mathrm{~m} \times 0.25 \mathrm{~mm} \times 0.5 \mu \mathrm{m})$. A FID detector was used for the analysis. The temperature ramp was programmed: from $30^{\circ} \mathrm{C}$ (hold time $10 \mathrm{~min}$ ) to $350^{\circ} \mathrm{C}$ at $10^{\circ} \mathrm{C} / \mathrm{min}$ ramp rate, with the final temperature maintained for 15 minutes.

Based on the gas chromatogram of the product we determined the conversion of the olefin compounds of the feedstock and the selectivity of the oligomerization reactions forming $\mathrm{C}_{8}-\mathrm{C}_{11}$ and $\mathrm{C}_{12+}$ hydrocarbons $\left(\mathrm{C}_{8}-\mathrm{C}_{11}\right.$ and $\mathrm{C}_{12+}$ selectivity; unit: relative $\%$ ).

With using simple GC and available industry samples with known composition and individual and mixture $\mathrm{C}_{4}-\mathrm{C}_{6}$ calibration standards the $\mathrm{C}_{4}-\mathrm{C}_{6}$ hydrocarbons can be determined exactly. The olefin content of the feedstock and the unconverted $\mathrm{C}_{4}-\mathrm{C}_{6}$ olefins in the liquid product can be clearly identified so - using mass balance - the defined olefin conversion can be calculated. We identified all of the hydrocarbons which were not in the feedstock as resulting products $\left(\mathrm{C}_{8+}\right.$ hydrocarbons $)$. Based on the end boiling point of feedstock it did not contain $\mathrm{C}_{8}$ hydrocarbons. Due to the difficulties of determination the detailed $\mathrm{C}_{8+}$ product analysis with a $\mathrm{GC}$ was not our aim, we could only determine the amount of heavier fractions as defined in number of carbon atoms.

Through evaluating the results we divided the $\mathrm{C}_{8+}$ products into two fractions according to carbon number, thus giving the $\mathrm{C}_{8-11}$ and $\mathrm{C}_{12+}$ selectivity $\left(\mathrm{C}_{8-11}\right.$ selectivity = weight of $\mathrm{C}_{8-11}$ hydrocarbon/weight of $\mathrm{C}_{8+}$ hydrocarbons $* 100, \mathrm{C}_{12+}$ selectivity $=100-\mathrm{C}_{8-11}$ selectivity). These data characterized the oligomerization reactions having taken place on the catalyst.

Testing methods applied for characterizing the catalysts used in the experiments are summarized in Table 1.

\subsection{Feedstock and catalysts}

Because of the reasons mentioned in the introduction, the experiments were carried out not with individual olefins but a light fraction produced with distillation from refinery FCC-naphtha (boiling point range: $30.6-88.0^{\circ} \mathrm{C}$, density at $15.6^{\circ} \mathrm{C}: 0.6561 \mathrm{~g} / \mathrm{cm}^{3}$ ) (Table 2 ). This contained mostly $\mathrm{C}_{5}-\mathrm{C}_{6}$ 
Tab. 1. Testing methods for the catalysts

\begin{tabular}{ll}
\hline Property/composition & Method \\
\hline Crystal structure & X-ray diffraction (XRD) with Philips PW \\
& $1730 / 10$ diffractometer (PW 1050/70 \\
& goniometer), CuKa radiation $(\lambda=1.5406$ \\
& $\AA ; U=40 \mathrm{kV} ;=35 \mathrm{~mA}$; scan rate: \\
& 0.02 degrees $2 \Theta / \mathrm{s})$ and graphite X-ray \\
& monochromator \\
& ESEM: Environmental Scanning Electron \\
Surface tests & Microscope \\
Specific surface & low temperature N2 adsorption (ASAP \\
Acidity & 2000 apparatus) \\
& Temperature programmed desorption \\
& (TPD) of chemisorbed ammonia \\
\hline
\end{tabular}

hydrocarbons. The concentration of the unsaturated components with olefinic double bond, which are important from the point of view of oligomerization, was $34.2 \%$.

Two of the eight zeolite catalysts being tested in the preexperiment, those showed the highest activity, were tested in detail. The oligomerization experiments were carried out on two ZSM-5 type zeolite catalysts (A and B) and on these two layered bed (1:1 volume ratio) (Table 3 , Figure 3$)$. In the tubular reactor was charged with $80 \mathrm{~cm}^{3}$ (A: $60.8 \mathrm{~g} / \mathrm{B}: 58.1 \mathrm{~g}$ ) catalyst and for the two layered bed $30+30 \mathrm{~cm}^{3}$ (A: $23.1 \mathrm{~g}+\mathrm{B}$ : $21.5 \mathrm{~g}$ ) as a catalyst, including $20 \mathrm{~cm}^{3}$ of inert loading (in the direction of the flow the first catalyst was filled in $\mathrm{B}$ then $\mathrm{A}$ ). The activation of the catalysts occurred at $400^{\circ} \mathrm{C}$ under an $\mathrm{H}_{2}$ atmosphere.

\section{Results and discussion}

Our object was to select a zeolite or a catalytic system containing two zeolite catalysts with different properties are suitable for oligomerization converting the olefin content of the feedstock to heavier isoolefins mixture. According to our objective we studied the oligomerization activity of two zeolites in a
Tab. 2. Composition of feedstock used in the experiments

\begin{tabular}{lc}
\hline Hydrocarbons & $\begin{array}{c}\text { Composition of light naphtha fraction } \\
\text { of fluid catalytic cracking, w/w\% }\end{array}$ \\
\hline butenes & 2.7 \\
i-pentane & 36.7 \\
pentenes & 4.6 \\
n-pentane & 4.2 \\
dimethyl-butene & 20.6 \\
2-methyl-pentene & 1.0 \\
methyl-pentane & 16.8 \\
hexene & 2.2 \\
hexane & 1.7 \\
methyl-cyclopentene & 1.7 \\
methyl-cyclopentane & 2.7 \\
cyclohexene & 0.8 \\
cyclohexane & 0.7 \\
other hydrocarbons & 3.6 \\
Total olefin & 34.2 \\
\hline
\end{tabular}

Tab. 3. Main properties of catalysts

\begin{tabular}{lcc}
\hline Properties & Catalyst A & Catalyst B \\
\hline Acidity, mmol $\mathrm{NH}_{3} / \mathrm{g}$ & 0.970 & 0.500 \\
Specific acidity, $\mathrm{mmol} \mathrm{NH} / \mathrm{m}^{2}$ cat. & 0.0051 & 0.0015 \\
Surface area $(\mathrm{BET}), \mathrm{m}^{2} / \mathrm{g}$ & 189 & 328 \\
Micropore volume, $\mathrm{cm}^{3} / \mathrm{g}$ & 0.0473 & 0.0776 \\
Macropore volume, $\mathrm{cm}^{3} / \mathrm{g}$ & 0.2880 & 0.2830 \\
Meso-/ micropore volume ratio & 6.1 & 3.6 \\
Average pore size, $\mathrm{nm}$ & 2.5 & 2.3 \\
\hline
\end{tabular}

wide range of process parameters. Based on the mass balance the quantity of the non-reactive hydrocarbons changed only in the range of ensemble error of technological and analytical measurements.
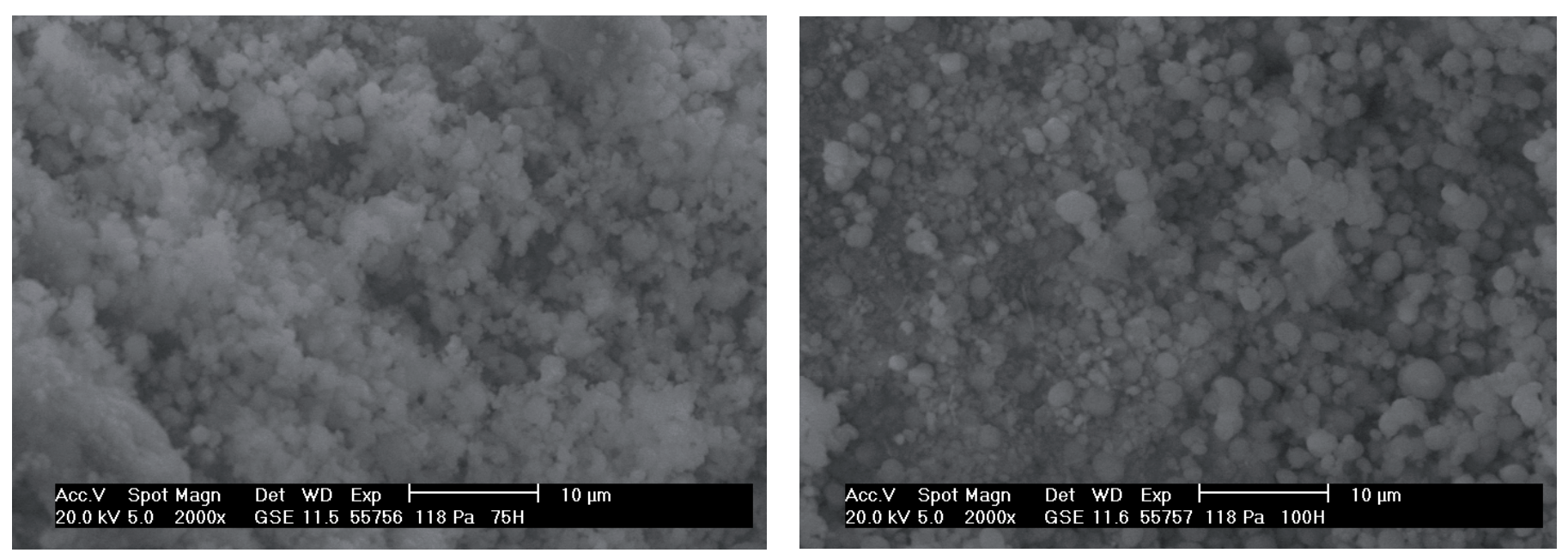

Fig. 3. Result of ESEM (Environmental Scanning Electron Microscope) of the catalysts (left: catalyst A, right: catalyst B) 


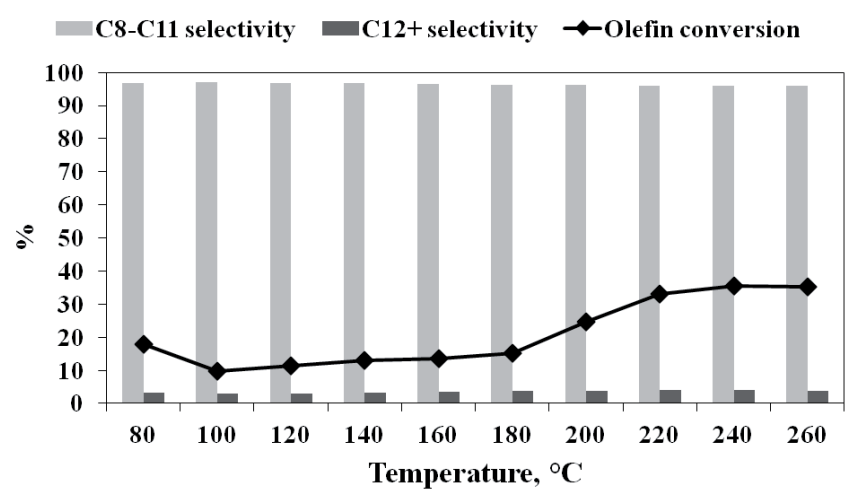

Fig. 4. The results achieved on catalyst $\mathrm{A}$ as a function of temperature (Pressure: 30 bar, Liquid hour space velocity: $2.0 \mathrm{~h}^{-1}$ )

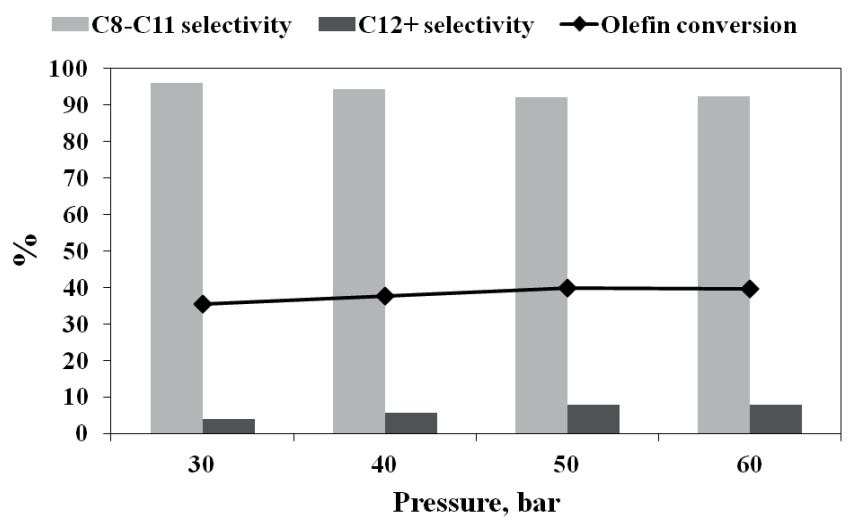

Fig. 5. The results achieved on catalyst $A$ as a function of temperature (Temperature: $240^{\circ} \mathrm{C}$, Liquid hour space velocity: $2.0 \mathrm{~h}^{-1}$ )

Investigating the temperature dependence of oligomerizing activity of zeolite A and B we found that the yield of the liquid products changed in range of $85-100 \%$. Reactions resulting gaseous products took only place above $200^{\circ} \mathrm{C}$.

Figure 4 and 5 show that in case of catalyst A the conversion of olefins varied between $9.9 \%$ and $39.8 \%$. In the studied parameter range the total oligomeric hydrocarbon share in the products was between 2.1 to $13.3 \mathrm{abs} \%$, the $\mathrm{C}_{12+}$ selectivity of oligomers (based on amount of $\mathrm{C}_{8+}$ products) varied between $3 \%$ and $8 \%$.

We found that the conversion of olefins and the share of heavier products increased with increasing the temperature to $240^{\circ} \mathrm{C}$ and above this there were only very slight changes. The maximum value was achieved at $240^{\circ} \mathrm{C}$ and 50 bar.

The results obtained on catalyst B are shown in Figures 6 and 7. The conversion of olefins was between $3 \%$ and $38.5 \%$, and the oligomers share in the product was between 0.2 and $12.3 \mathrm{abs} \%$. In the investigated process parameter range the $\mathrm{C}_{12+}$ oligomers selectivity varied between 0 and $9 \%$. We found that the activity of catalyst changed similarly to those experienced in the case of catalyst $\mathrm{A}$ in function of temperature and pressure. Increase in pressure favoured for $\mathrm{C}_{12+}$ selectivity.

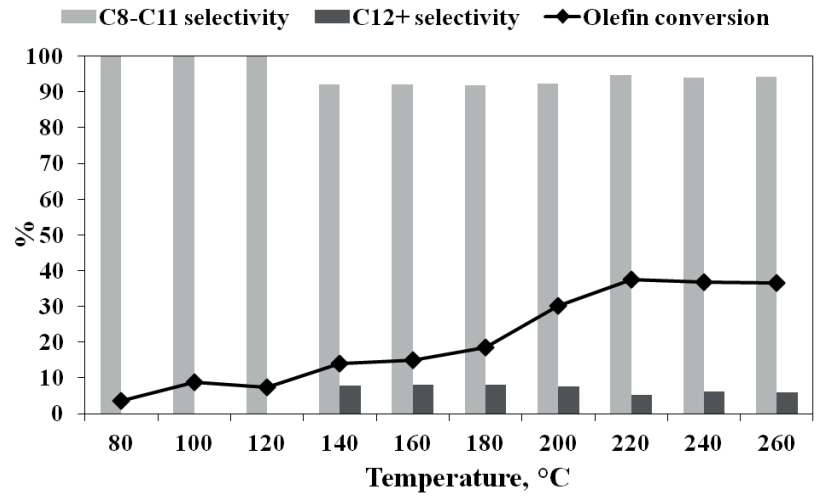

Fig. 6. The results achieved on catalyst $\mathrm{B}$ as a function of temperature (Pressure: 30 bar, Liquid hour space velocity: $2.0 \mathrm{~h}^{-1}$ )

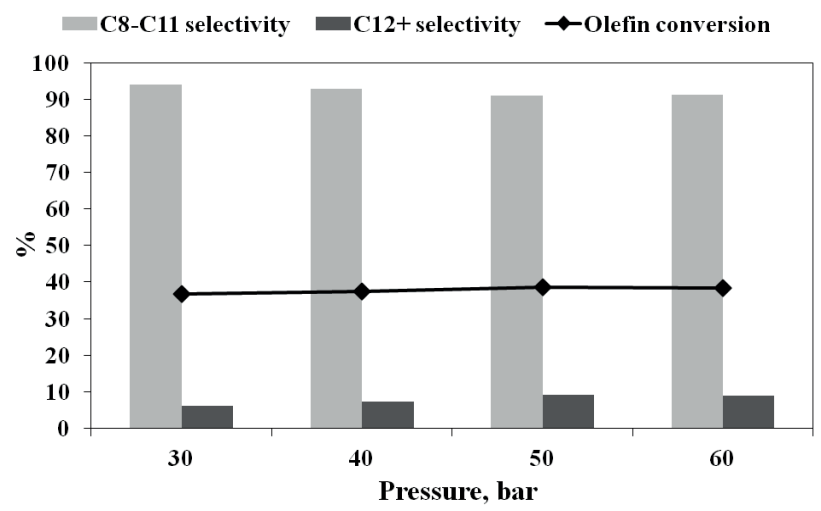

Fig. 7. The results achieved on catalyst $\mathrm{B}$ as a function of pressure (Temperature: $240{ }^{\circ} \mathrm{C}$, Liquid hour space velocity: $2.0 \mathrm{~h}^{-1}$ )

Based on result of the experiments we found that the activity of both catalysts was not significantly different from each other at the applied process parameters; the compositional and structural differences between them cause only 1-2 percent absolute deviation in the olefin conversion (catalyst A: $39.8 \%$ and catalyst B: $38.5 \%$ ) and in $\mathrm{C}_{12+}$ selectivity (catalyst A: $8 \%$ and catalyst B: $9 \%$ ) values.

In the further experiments we examined the application of catalyst A and B together in two layered bed as a new catalytic system (Figure 8). Reasons of using of two layered bed were mainly technological considerations. In case of highly exothermic reactions (e.g. oligomerization) on the inert bed the temperature decreases, so the rate of cracking side reactions, too. In addition in the case of industrial implementation it is possible with divided bed to cool the reaction mixture with fresh feedstock. In technical terms, its application increases the efficiency the redistribution of the hydrocarbon mixture on an inert bed. Favourable temperature for the oligomerization was higher - on the basis of the results of previous experiments.

On the basis of the results we found that cracking reactions (resulting gaseous products) took place in higher extent at higher temperatures $\left(>250^{\circ} \mathrm{C}\right)$ in the investigated temperature 


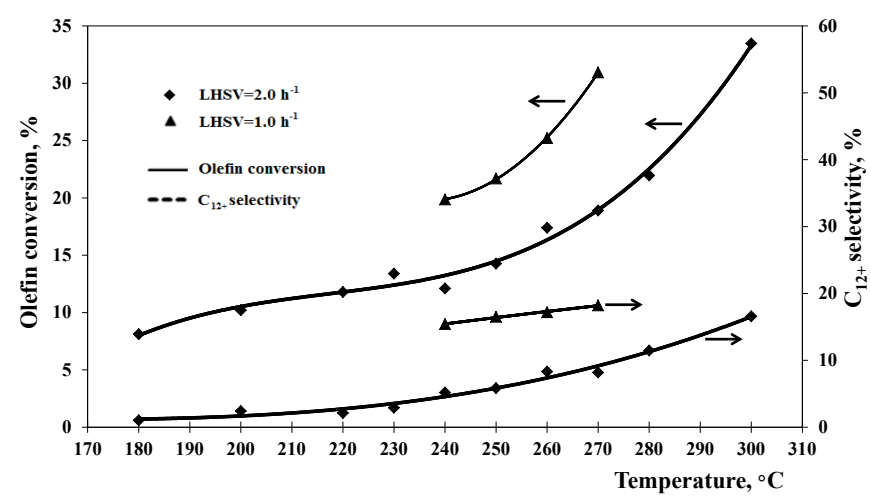

Fig. 8. Results achieved on two layered catalyst bed (Pressure: 40 bar)

range, which significantly reduced the yield of the liquid products $(65-98 \%)$.

The olefin conversion was between 6.9 to $33.5 \%$, whereas the concentration of formed heavier hydrocarbons changed between 2.9 to 11.2 abs\% depending on the temperature. With the reduction of LHSV both the olefin conversion and the $\mathrm{C}_{12+}$ selectivity became higher. The largest oligomer share in the product was reached at $270^{\circ} \mathrm{C}, 40$ bar and $1.0 \mathrm{~h}^{-1} \mathrm{LHSV}$ (liquid yield: $76 \%$, olefin conversion: $33.5 \%, \mathrm{C}_{8}-\mathrm{C}_{11}$ selectivity: $81.8 \%, \mathrm{C}_{12+}$ selectivity: $18.2 \%$ ).

We found that the conversions were lower than those found by others in experiments with model compounds [7-14]. This was expected, because the applied feedstock contained relatively large amounts of materials inert to oligomerization (approx. $65.8 \%$ ), which reduce the probability of occurring target reactions with temporary covering of the catalytically active sites.

During the two layered bed experiments, however, the $\mathrm{C}_{12+}$ selectivity was higher, at favourable conditions it approximately doubled in comparison to the value obtained with a single zeolite catalyst bed (e.g. catalyst A). This was mainly due to the less liquid hour space velocity at a given temperature $\left(260^{\circ} \mathrm{C}\right)$. Twice the selectivity was achieved at higher temperatures. The oligomerizing activity of the catalyst increased significantly at $300^{\circ} \mathrm{C}$, however, with largely increasing of the cracking activity reduced the yield of the target products (65\%).

Activity of catalysts did not show significant decrease at the examined process parameter range during the experiments. Our feedstock is a light hydrocarbon fraction, so it did not contain high molecular weight coke precursors, but they could form in polymerization reactions. After removing the catalyst we did not observe any signs of coke formation.

There are Engler distillation curves of the typical products used with the different catalyst bed compared to the distillation curve of the feedstock (Figure 9). Shape of the curves supports well the previous evaluation, and the beneficial effect of the application of layered bed. At a higher temperature higher degree oligomers are formed in a greater volume, and the end

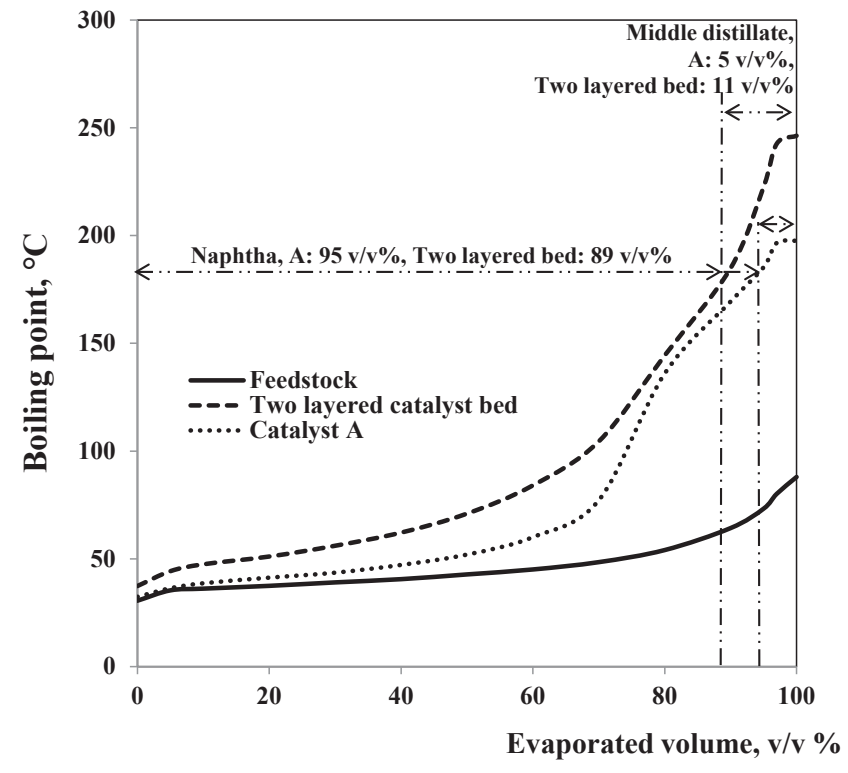

Fig. 9. The distillation curve of the obtained products compared to the distillation curve of the feedstock (Temperature: $240^{\circ} \mathrm{C}$, Pressure: 40 bar, Liquid hour space velocity: $2.0 \mathrm{~h}^{-1}$ )

boiling point of the product increased. It can be seen that at lower conversion the shape of the curves are staged due to the forming of different degree oligomers, at strict parameters - for example at higher temperature - the different reactions resulted more balanced hydrocarbon distribution. The liquid hydrocarbon product obtained at the favourable process conditions contains about $89 \mathrm{v} / \mathrm{v} \%$ naphtha and about $11 \mathrm{v} / \mathrm{v} \%$ middle distillate boiling range products in case of layered bed.

Catalytic hydrogenation of oligomerizatums is not a topic of this paper, even so based on the results of the hydrogenation of oligomerizatums (on $\mathrm{Pt}, \mathrm{Pd} / \mathrm{Al}_{2} \mathrm{O}_{3}$ catalyst) the octane number of the naphtha product reached 100 , the crystallization point of the JET fuel was low $\left(-55^{\circ} \mathrm{C}\right)$, the cetane number of the gas oil product was high $(>65)$ and it had a good CFPP (cold filter plugging point) value $\left(-15^{\circ} \mathrm{C}\right)$ (Table 4). However, it could also meet the required standard value after using a low amount of additive.

\section{Summary}

The favourable combination of process parameters by investigating the oligomerization of light FCC naphtha olefins was $\mathrm{T}=240^{\circ} \mathrm{C}, \mathrm{P}=50 \mathrm{bar}, \mathrm{LHSV}=2.0 \mathrm{~h}^{-1}$, in case of both ZSM -5 zeolite catalysts. At these process parameters the olefin conversions were 39.8 and $38.5 \%$, and the shares of $\mathrm{C}_{12+}$ hydrocarbons in the oligomer product (related to $\mathrm{C}_{8+}$ hydrocarbons) were 8.0 and $9.0 \%$. In case of the application of zeolite catalysts A and B in two layered bed the olefin conversion was $33.5 \%\left(\mathrm{~T}: 270^{\circ} \mathrm{C}\right.$, P: 40 bar, LHSV: $1.0 \mathrm{~h}^{-1}$ ) with $18.2 \% \mathrm{C}_{12+}$ selectivity.

The oligomerizing activity of the tested catalytic systems was similar using zeolite A and B separately. However, when applying the two layered zeolite catalyst bed it approximately doubled the oligomers ratio in the middle distillate boiling 
Tab. 4. Main properties of typical products

\begin{tabular}{|c|c|c|c|c|c|c|}
\hline \multirow[b]{2}{*}{ Properties } & \multicolumn{2}{|c|}{ Naphtha } & \multicolumn{2}{|c|}{ JET A1 } & \multicolumn{2}{|c|}{ Gas oil } \\
\hline & $\begin{array}{c}\text { Hydrogenated } \\
\text { oligomer product }\end{array}$ & $\begin{array}{c}\text { EN } \\
228: 2012\end{array}$ & $\begin{array}{l}\text { Hydrogenated } \\
\text { oligomer product }\end{array}$ & $\begin{array}{c}\text { EN } \\
10870: 2012\end{array}$ & $\begin{array}{l}\text { Hydrogenated } \\
\text { oligomer product }\end{array}$ & $\begin{array}{l}\text { EN 590:2013 } \\
\text { +A1 } 2010\end{array}$ \\
\hline Yield, v/v\% & 89 & & 8 & & 3 & \\
\hline Research octane number & appr. 100 & $\begin{array}{c}\min 95 \\
98\end{array}$ & - & - & - & - \\
\hline Crystallization point, ${ }^{\circ} \mathrm{C}$ & - & - & -55 & $\max -47$ & - & - \\
\hline Cetane number & - & - & - & - & $>65$ & $\min 51$ \\
\hline $\mathrm{CFPP}^{*},{ }^{\circ} \mathrm{C}$ & - & - & - & - & -15 & $\begin{array}{c}\max -20 \\
\text { or }+5\end{array}$ \\
\hline
\end{tabular}

*CFPP: cold filter pugging point

point range. However, because of the used higher temperatures the yield of liquid product was greatly reduced.

We did not achieve significant increasing of efficiency with the use of two layered bed in large laboratory scale. The application of it has primarily importance in case of increased size technology.

One advantage of the application of two layered bed is that the catalyst bed temperature could be controlled more easily in spite of the exothermic oligomerization reactions. To this the large inert hydrocarbon content of the feedstock contributes, which is non-reactive in oligomerization reactions.

So isoolefin mixtures can be prepared in favourable reaction conditions, from which after the saturation of the olefinic double bonds and distillation excellent, environmentally friendly gasoline, JET and gas oil blending components can be obtained.

\section{References}

1 Hancsók J., Kasza T., The Importance of Isoparaffins at the Modern Engine Fuel Production. in 'Proceeding 8th International Colloquium Fuels 2011. Stuttgart/Ostfildern, Germany', pp. 361-373, (2011).

2 CEN Workshop, Automotive fuels-Blends of paraffinic diesel from synthesis (XTL) or hydrotreatment (HVO) and fatty acid methyl esters (FAME)-Requirements and test methods. WS61/N002, Final Business Plan, (2010).

3 de Klerk A., Furimsky E., Catalysis in the Refining of FischerTropsch Syncrude. The Royal Society of Chemistry, Cambridge (2010). DOI: $\underline{10.1039 / 9781849732017}$

4 Prinsloo N. M., Solid phosphoric acid oligomerisation: Manipulating diesel selectivity by controlling catalyst hydration. Fuel Processing Technology, 87 (5), pp. 437-442, (2006).

DOI: 10.1016/j.fuproc.2005.11.005

5 Coetzee J. H., Mashapa T. N., Prinsloo N. M., Rademan J. D., An improved solid phosphoric acid catalyst for alkene oligomerization in a Fischer-Tropsch refinery. Applied Catalysis A: General, 308 (10), pp. 204-209, (2006). DOI: $10.1016 /$ j.apcata.2006.04.023

6 Sakuneka T. M., de Klerk A., Nel R. J. J., Pienaar A. D., Synthetic Jet Fuel Production by Combined Propene Oligomerization and Aromatic Alkylation over Solid Phosphoric Acid. Industrial and Engineering Chemistry Research, 47 (6), pp. 1828-1834, (2008). DOI: $10.1021 / \mathrm{ie} 0710566$

$7 \quad$ Nkosi B., Ng F. T. T., Rempel G. L., The oligomerization of 1-butene using NaY zeolite ion-exchanged with different nickel precursor salts. Applied Catalysis A: General, 161 (1-2), pp. 153-166, (1997). DOI: $\underline{10.1016 / \mathrm{S} 0926-860 \mathrm{X}(97) 00049-5}$

8 Nkosi B., Ng F. T. T., Rempel G. L., The oligomerization of butenes with partially alkali exchanged NiNaY zeolite catalysts. Applied Catalysis A: General, 158 (1-2), pp. 225-241, (1997). DOI: 10.1016/S0926-860X(96)00420-6

9 Yoon J. W., Chang J. S., Lee H. D., Kim T. J., Jhung S. H., Trimerization of isobutene over a zeolite beta catalyst. Journal of Catalysis, 245 (1), pp. 253-256, (2007).

DOI: $10.1016 /$ j.jcat.2006.10.008

10 Yoon J. W., Jhung S. H., Choo D. H., Lee S. J., Lee K. Y., Chang J. S., Oligomerization of isobutene over dealuminated $Y$ zeolite catalysts. Applied Catalysis A: General, 337 (1), pp. 73-77, (2008).

DOI: 10.1016/j.apcata.2007.12.001

11 Yoon J. W., Jhung S. H., Lee J. S., Chang J. S., Lee K-Y., Oligomerization of isobuetene over alumiunium chloride-loaded USY zeolite catalysts. Journal of Porous Materials, 16 (6), pp. 631-634, (2009).

DOI: $\underline{10.1007 / \mathrm{s} 10934-008-9242-7}$

12 de Klerk A., Oligomerization of 1-Hexene and 1-Octene over Solid Acid Catalysts. Industrial and Engineering Chemistry Research, 44 (11), pp. 3887-3893, (2005). DOI: $10.1021 / \mathrm{ie} 0487843$ 
13 de Klerk A., Properties of Synthetic Fuels from H-ZSM-5 Oligomerization of Fischer-Tropsch Type Feed Materials. Energy and Fuels, 21 (6), pp. 3084-3089, (2007).

DOI: $10.1021 / \mathrm{ef} 700246 \mathrm{k}$

14 Yoon J. W., Jhung S. H., Kim T. J., Lee H. D., Jang N.H., Chang J. S., Trimerization of Isobutene over Solid Acid Catalysts under Wide Reaction Conditions. Bulletin of the Korean Chemical Society, 28 (11), pp. 2075-2078, (2007). DOI : $\underline{10.5012 / \text { bkcs.2007.28.11.2075 }}$

15 Yoon J. W., Jhung S. H., Chang J. S., Trimerization of Isobutene over Solid Acid Catalysts: Comparison between Cation-exchange Resin and Zeolite Catalysts. Bulletin of the Korean Chemical Society, 29 (2), pp. 339-341, (2008)

DOI: $10.5012 /$ bkcs.2008.29.2.339

16 Yoon J. W., Jhung S. H., Lee H-D., Kim T-J., Chang J. S., Trimerization of isobutene over cation exchange resins: Effect of physical properties of the resins and reaction conditions. Journal of Molecular Catalysis A: Chemical, 260 (1-2), pp. 181-186, (2006).

DOI: $10.1016 /$ j.molcata.2006.07.026

17 Ouni T., Honkela M., Kolah A., Aittamaa J., Isobutene dimerisation in a miniplant-scale reactor. Chemical Engineering and Processing: Process Intensification, 45 (5), pp. 329-339, (2006). DOI: $10.1016 /$ j.cep.2005.09.005

18 Alcántara R., Alcántara E., Canoira L., Franco M. J., Herrera M., Navarro A., Trimerization of isobutene over Amberlyst-15 catalyst. Reactive and Functional Polymers, 45 (1), pp. 19-27, (2000). DOI: $10.1016 / \mathrm{S} 1381-5148(00) 00004-3$

19 Bringué R., Cadenas M., Fité C., Iborra M., Cunill F., Study of the oligomerization of 1-octene catalyzed by macroreticular ion-exchange resins. Chemical Engineering Journal, 207-208, pp. 226-234, (2012).

DOI: 10.1016/j.cej.2012.06.089

20 Kriván E., Valkai I., Hancsók J., Investigation of Production of Motor Fuel Components on Heterogeneous Catalyst with Oligomerization. Topics in Catalysis, 56 (9-10), pp. 831-838, (2013). DOI: $10.1007 / \mathrm{s} 11244-013-0041-2$

21 Tzompantzi F., Mantilla A., Angel G. D., Padilla J. M., Fernandez J. L., Diaz-Gongora J. A. I., Gomez R., NiO-W2O3/Al2O3 catalysts for the production of ecological gasolinen: Effect of both $\mathrm{NiO}$ and the preparation method on the isobutene oligomerization selectivity. Catalysis Today, 143 (1), pp. 132-136, (2009). DOI: 10.1016/j.cattod.2008.09.022
22 Lee J. S., Yoon J. W., Halligudi S. B., Chang J-S., Jhung S. H., Trimerization of isobutene over WOx/ZrO2 catalysts. Applied Catalysis A: General, 366 (2), pp. 299-303, (2009).

DOI: $10.1016 / j$.apcata.2009.07.016

23 Gu Y., Shi F., Deng Y., SO3H-functionalized ionic liquid as efficient, green and reusable acidic catalyst system for oligomerization of olefins. Catalysis Communications, 4 (11), pp. 597-601, (2003). DOI: 10.1016/j.catcom.2003.09.004

24 Fehér Cs., Kriván E., Hancsók J., Skoda-Földes R., Oligomerization of isobutene with silica supported ionic liquid catalysts. Green Chemistry, 14 (2), pp. 403-409, (2012).

DOI: $10.1039 / \mathrm{C} 1 \mathrm{GC} 15989 \mathrm{E}$

25 Liu S., Shang J., Zhang S., Yang B., Deng Y., Highly efficient trimerization of isobutene over silica supported chloroaluminate ionic liquid using C4 feed. Catalysis Today, 200 (1), pp. 41-48, (2013). DOI: $10.1016 /$ j.cattod.2012.06.023

26 Fehér Cs., Kriván E., Kovács J., Hancsók J., Skoda-Földes R., Support effect on the catalytic activity and selectivity of SILP catalysts in isobutene trimerization. Journal of Molecular Catalysis A: Chemical, 372, pp. 51-57, (2013). DOI: $\underline{10.1016 / j . m o l c a t a .2013 .02 .008}$

27 Hauge K., Bergene E., Chen D., Fredriksen G. R., Holmen A., Oligomerization of isobutene over solid acid catalysts. Catalysis Today, 100 (3-4), pp. 463-466, (2005). DOI: $10.1016 /$ j.cattod.2004.08.017

28 Kresnawahjuesa O., Kühl G. H., Gorte R. J., Quierini C. A., An examination of Bronsted acid sites in $\mathrm{H}-[\mathrm{Fe}] \mathrm{ZSM}-5$ for olefin oligomerization and adsorption. Journal of Catalysis, 210 (1), pp. 106-115, (2002) DOI: $10.1006 /$ jcat.2002.3657

29 Schmidt R., Welch M. B., Randolph B. B., Oligomerization of C5 olefins in light catalytic naphtha. Energy and Fuels, 22 (2), pp. 1148-1155, (2008). DOI: $\underline{10.1021 / \mathrm{ef} 800005 \mathrm{v}}$

30 Olivier-Bourbigou H., Forestiere A., Saussine L., Magna L., Favre F., Hugues F., Olefin oligomerization for the production of fuels and petrochemicals. Oil Gas European Magazine, 36 (2), pp. 97-102, (2010). 